\title{
THE IMPACT OF DIGITALIZATION ON THE AUDIT PROFESSION: A REVIEW OF TURKISH INDEPENDENT AUDIT FIRMS
}

DOI: 10.17261/Pressacademia.2019.1164

JBEF- V.8-ISS.4-2019(3)-p.209-214

Burcu Adiloglu ${ }^{1}$, Nevzat Gungor ${ }^{2}$

${ }^{1}$ Istanbul University, Avillar Campus, Faculty of Business Administration, Accounting Department, Istanbul, Turkey. adiloglu@istanbul.edu.tr, ORCID: 0000-0001-9680-1408

2 Istanbul University, Avcilar Campus, Faculty of Business Administration, Accounting Department, Istanbul, Turkey. nevzat.gungor@istanbul.edu.tr, ORCID: 0000-0001-9883-1985

Date Received: July 1, 2019

Date Accepted: November 16, 2019

To cite this document

Adiloglu, B., Gungor, N., (2019). The impact of digitalization on the audit profession: a review of Turkish independent audit firms. Journal of Business, Economics and Finance (JBEF), V.8(4), p.209-214.

Permemant link to this document: http://doi.org/10.17261/Pressacademia.2019.1164

Copyright: Published by PressAcademia and limited licenced re-use rights only.

\begin{abstract}
Purpose - The aim of exploratory study is to increase the understanding of the effects digitalization has on the tools and working methods of the audit profession.

Methodology - Websites of 235 audit firms authorized by POA (Public Oversight, Accounting and Auditing Standards Authority) were examined. In addition, transparency reports of 64 companies authorized for Public Interest Entity (PIE) Audit were investigated as well. The status of the services provided by the audit companies after the technological developments were analyzed. In addition, infrastructure and continuous education investments of audit firms related to digitalization have been determined.

Findings- It has been found that almost all audit companies provide services for independent audit and tax audit. (Respectively $95 \%$ and $85 \%$ ). These are followed by financial services and internal audit issues. (Respectively $61 \%$ and $45 \%$ ). Only Big Four invest the necessary infrastructure and human resources in addition to providing services in these matters. In spite of all these technological developments, only 24 companies provide education to their employees for IT / IT audits. Only Big Four provide education for digital technologies to their employees.

Conclusion- As a result, with the effect of digitalization, Information technologies have gained importance. But the audit firms have not yet made the necessary investment in these areas. $90 \%$ of audit firms do not provide services in these areas and do not make infrastructure and human resources investments.
\end{abstract}

Keywords: Digitalization, information technologies, accounting, audit, auditing firms. JEL Codes: M40, M41, M42

\section{INTRODUCTION}

An independent audit is an examination of the financial records, accounts, business transactions, accounting practices by an "independent" auditor. According to Flint (1988) the original purpose of auditing was to find out if certain duties were met honestly, with properness and in accordance with regulations and specific instructions. Companies prepare their financial statements in accordance with a framework of generally accepted accounting principles (GAAP) relevant to their country, also referred as accounting standards or financial reporting standards. Auditing can be seen as a special kind of examination that is a part of securing accountability, performed by a person other than the parties involved.

For as long as humans have existed, there has been technological development. During the recent years, the development of technology and digitalization have led to the globalization of business world especially accounting profession. It is important to realize how the accounting and audit profession is affected by technology and digitalization.

What impact digitalization will have on the audit profession is unknown, in that it is still a growing event. However, in the report prepared by FAR (2016), they anticipate that the automation and digitization of the accounting field will bring about structural 
changes that will have a profound impact on the entire audit profession. FAR (2016) insists that further development is necessary, but "One thing we know for certain is that our time is not close to what the future will be" (FAR, 2016).

In recent years, digitization has been seen as one of the most important events that will have a major impact on the audit profession and will lead to changes. In this study, current status of the audit profession in Turkey will be examined. In addition, the effect of digitalization on the audit profession will be determined.

\subsection{Digitalization}

As companies move towards digital business models, more and more data are being exchanged between organizations, partners and customers. Digital information, the source of life for today's interconnected ecosystems, is becoming increasingly valuable for companies. In today's golden age of digitalization; data, data review and data audit are important challenges to accounting and audit profession. Developments in digitalization and information technologies will lead to changes in the accounting and auditing profession. In particular, the services and professional practices provided by audit firms will reshape with the effect of these changes.

This part of the study, artificial intelligence, big data, blockchain and cyber security issues which are very important in digitalization and information technologies are discussed. These issues are explained conceptually and their effects on the accounting and auditing profession are summarized.

\subsubsection{Artificial intelligence}

Artificial intelligence (Al) is defined as: intelligence exhibited by machines. In computer science, an ideal "intelligent" machine is a flexible rational agent that perceives its environment and takes actions that maximize its chance of success at some goal. Generally, the term "artificial intelligence" is applied when a machine mimics "cognitive" functions that humans associate with other human minds, such as "learning" and "problem solving." (Issa, H. et. al, 2016).

$\mathrm{Al}$ is currently being implemented in a variety of areas, including vehicle-free, home energy systems and investment portfolio management. Accounting and auditing will also be affected. The effects of artificial intelligence on the audit profession can be summarized as follows: (E\&Y, 2018)

- $\quad$ Machine learning can be used to automatically record accounting transactions.

- $\quad$ Creating models based on advanced machine learning auditors can also improve fraud detection.

- Al can analyze unstructured data such as emails, social media broadcasts, and conference call audio files.

- $\quad$ Al will help auditors optimize their time, enabling them to use their human judgment to analyze a broader and deeper set of data and documents.

\subsubsection{Big Data and Data Analytics}

Big data refers to datasets whose size is beyond the ability of typical database software tools to capture, store, manage, and analyze. (McKinsey, 2011). More importantly, for auditors, data in big data means the collection of multiple types of data that may include a mix of traditional structured financial and non-financial data, logistics data, sensor data, emails, phone calls, and social media data, blogs, as well as other internal and external data. The traditional focus of auditors on transactional data, and therefore a particularly relevant content definition of big data in the audit context, is taken by Connolly (2012) as the starting point for transactions: (Alles et. al, 2015)

Big Data $=$ Transactions + Interactions + Observations

Big data provides higher quality audit evidence and more relevant business insights. Big data and analytics enable auditors to better identify financial reporting, fraud and operational business risks, and adapt their approach to providing a more relevant audit. The automatic acquisition of data via sensors, RFID (Radio Frequency recognition) and GPS data streams allows the addition of large number of sources of audit evidence. For example, instead of using methods such as LIFO and FIFO to determine inventory costs, the use of data from RFID or barcode systems, one of the big data sources, facilitates real-time monitoring of inventory costs. One of the big data elements is the capital markets files, e-mails, web pages, social media and media news. These data are tools that contribute to the evaluation and improvement of processing performance. (Aslan and Özerhan, 2017).

\subsubsection{Blockchain}

A block chain or blockchain is a distributed database that maintains a continuously growing list of data records that are hardened against tampering and revision, even by operators of the data store's nodes. (Fanning and Center, 2016). The 
blockchain, which started to spread since 2008, is developing rapidly in a structure that has the opportunity to transform and destroy many sectors. Especially in recent years, blockchain technology has gone beyond Bitcoin and has become a controversial concept in many business areas. However, since blockchain technology is a continuously developing field, it is known that it is not yet possible to fully demonstrate its effects at the business level. (Uçma and Kurt, 2018)

Blockchain technology offers users advantages at various points. The blockchain records the transactions performed by all participants in a single book and enables this service to be performed without centralized transaction processes. Since each blockchain stores copies of previous operations within the chain, it is also possible to reach each one retrospectively. (Deloitte, 2017). In particular, the absence of a central authority or administration control ensures that all changes are viewed, approved and recorded by all users. The transparency of the system becomes even more important as it does not allow the elimination / deletion or modification of the transactions performed. (Ovenden, 2017). The blockchain allows to record actual transactions in almost real time. However, it eliminates the risk of payment or collection made by a user. A blockchain comprises a verifiable record of each process performed on the chain. This also prevents repetitive recording of the traceable element by the blockchain. Furthermore, the fact that transactions cannot be altered or intervened after recording has increased the fair presentation of the data produced by the system. (Deloitte, 2017).

\subsubsection{Cybersecurity}

The concept of cybersecurity refers to measures taken to protect company data held on computer-based systems from the risks of loss, damage, unauthorized access and misuse of unauthorized persons. As explained in IIA's manual called '2016 Global Perspectives and Understanding: Internal Audit as a Trusted Cyber Advisor' "Cybersecurity should be addressed in a holistic manner and systematically in all institutions because the inability of an institution to provide cybersecurity can lead to inadequacy to carry out its most basic activities, loss of intellectual property rights, and even great damage to its reputation." (IIA, 2016). Governments across the globe have come to realize that cybersecurity is increasingly important not only for public sector institutions, military institutions and critical national substructure organizations, but also for private sector companies. Besides that, cybersecurity is a technology related and business related risk. Cyber-attacks for both the private and public companies in many different sectors are the most common and greatest risks that these companies face today. Cybersecurity violations may affect;

- financial systems and assets through misuse, theft and extortion

- intellectual property rights and business secrets through spying

- the brand and internet assets through defamation, accusation and disclosure of secrets

- business continuity through sabotage and interruption of operations.

Digital transformation requires the business world to make significant investments in cybersecurity. In addition, the specialization of internal auditors in the field of cybersecurity will contribute significantly to the objectives of internal audit in terms of adding value to the enterprises and protecting the business assets against all kinds of damages. The challenge of keeping up with the rapid evolution of digital technologies and the need for expertise raise awareness about cybersecurity and make creation of necessary substructure vital in developing countries which have sensitive economic balance like Turkey.

\subsubsection{Cloud Computing}

Essentially, cloud computing is a kind of outsourcing of computer programs. Cloud computing is rooted in search engine platform design. There are 5 major technical characteristics of cloud computing: (1) large scale computing resources (2) high scalability \& elastic (3) shared resource pool (virtualized and physical resource) (4) dynamic resource scheduling and (5) general purpose. (Qian et al., 2009).

As in many other fields, it is seen that cloud computing is increasingly used in accounting and auditing. Cloud computing has many effects and contributions to the accounting and auditing profession.

With the use of cloud-based accounting software, especially professionals can work independently from time and space and can access all kinds of information over the internet to serve customers faster and reach more customers. Customer or user can be defined to the system without paying additional license fee. also, there is no additional charge for software updates. This significantly reduces costs. Since the accounting data entered in the cloud systems are continuously recorded as multiple copies in the headquarters of the service provider and in the backup units outside the center, the company also protects against data loss caused by a negative event (natural disaster or malicious initiatives). Costs for backup are also prevented. Legal documents that need to be sent to public institutions are easily sent over the cloud system. (Öz, 2016) 


\section{LITERATURE REVIEW}

Kiesow et al. (2014) developed Continuous Auditing (CA) approach to cover the requirements to AIS in Big Data Computing Environments in their study. Since, the implementation of CA is a recognized challenge among researchers and practitioners, and traditional audit tools and techniques neglect the potential of Big Data Analytics, they strived for the development of appropriate computer-assisted audit tools and techniques (CAATTs). Therefore, they analyzed established CAATTs considering the dimensions of the Big Data paradigm in their research. To do so, they analyzed relevant literature and viewpoints of occupational organizations. They proposed a model for the integrated audit approach.

Alles and Gray (2015) aim to provide a balanced discussion of both the pros and the cons regarding incorporating Big Data into financial statement audits; and present a research agenda to identify specific aspects of Big Data that could benefit auditors.

Issa et al. (2016) propose various areas of Al-related research to examine where this emerging technology is most promising. Moreover, the paper raises a series of methodological and evolutionary research questions aiming to study the Al-driven transformation of today's world of audit into the assurance of the future.

Aslan and Özerhan (2017) reveal definition of Big Data, opportunities, challenges, accounting practices and its effects on accounting profession. According to the demographic factors, the perspectives of professional accountants operating in Turkey have been determined through a questionnaire about the impact of Big Data on accounting profession in next 10 years. The questionnaire was applied to 790 professional accountants and 740 valid questionnaires were taken into consideration. According to the results, accounting profession have different views about the effects of the BIG DATA on accounting profession over the next 10 years according to the demographic variables such as generation, gender, professional experience, place of residence, graduated faculty and working styles.

Karlsen and Wallberg (2017) aim to increase the understanding of the effects digitalization has on the tools and working methods of the audit profession. This is achieved through 14 semi-structured interviews with practicing auditors, where emphasis is put on interpretation. Conclusions drawn are that the effect on the auditors' working methods are more prominent than on the tools, due to paperless working methods and increased flexibility. Unlike previous research, this study also discovers an increasing effect - education. Thereby, education is underlined as important among auditors, where institutions also have to develop available education to the new competence needed.

Turker (2018) explains the developments and studies on shaping the global accounting profession to meet the expectations of the global business world according to the digital world.

Sabillon, R et al. (2017) examined the best practices and methodologies of global leaders in the cybersecurity assurance and audit arena. The article presents an original and comprehensive cybersecurity audit model as a proposal to be utilized for conducting cybersecurity audits in organizations and Nation States. The Cybersecurity Audit Model (CSAM) evaluates and validates audit, preventive, forensic and detective controls for all organizational functional areas. They tested, implemented and validated CSAM along with the Cybersecurity Awareness Training Model (CATRAM) in a Canadian higher education institution.

Uçma and Kurt (2018) discuss innovations brought by block-chain technology into the field of accounting and control. Then the study addresses the necessity of preparing professional members' future record keeping system on the basis of block-chain technology. Thus, the study draws attention to block-chain-based accounting and auditing practices and explains the professional qualification requirements that each member of the profession shapes in response to this innovation.

\section{DATA AND METHODOLOGY}

The aim of exploratory study is to increase the understanding of the effects digitalization has on the tools and working methods of the audit profession. For this purpose, websites of 235 audit firms authorized by POA (Public Oversight, Accounting and Auditing Standards Authority) were examined. In addition, transparency reports of 64 companies authorized for Public Interest Entity (PIE) Audit were investigated as well.

The status of the services provided by the audit companies after the technological developments were analyzed. In addition, infrastructure and continuous education investments of audit firms related to digitalization have been determined.

The sample we used consists of the 235 of the 273 audit firms (38 firms' web sites could not be reached) which are listed in POA's web site. The distribution of 235 companies by cities and authorization information of the firms are shown: 
Table 1: Distribution of Audit Companies by Cities

\begin{tabular}{|l|c|c|c|}
\hline Cities & \# Of Audit Firm & Cities & \# Of Audit Firm \\
\hline İstanbul & 132 & Adana & 1 \\
\hline Ankara & 38 & Denizli & 1 \\
\hline İzmir & 18 & Elazı̆̆ & 1 \\
\hline Bursa & 13 & Eskişehir & 1 \\
\hline Antalya & 8 & Kocaeli & 1 \\
\hline Gaziantep & 7 & Kütahya & 1 \\
\hline Kayseri & 3 & Malatya & 1 \\
\hline Samsun & 3 & Manisa & 1 \\
\hline Şanlıurfa & 2 & Mersin & 1 \\
\hline Sakarya & 1 & Tekirdağ & 1 \\
\hline
\end{tabular}

According to Table 1, There are 20 different cities where audit firms locate. Most of the audit firms operate in Istanbul (132 firms). Istanbul is followed by Ankara and Izmir (respectively 38, 18 firms).

\section{Table 2: Authorizations of Audit Companies}

\begin{tabular}{|l|l|}
\hline Authorization & \# of Audit firm \\
\hline Basic Audit Power & 115 \\
\hline Audit Power on PIE's Additionally Excluding Insurance Etc. & 64 \\
\hline Audit Power on PIE's Additionally & 56 \\
\hline Total & $\mathbf{2 3 5}$ \\
\hline
\end{tabular}

As shown in Table 2, 115 audit firms have only basic audit power. 64 of the other 120 companies have Audit Power on PIE's Additionally Excluding Insurance Etc. and rest of the firms have Audit Power on PIE's Additionally.

\section{FINDINGS AND DISCUSSIONS}

Initially, to analyze the effects of digitalization on audit profession and services 235 companies' website disclosure were examined and services provided by firms detected.

\section{Table 3: Services Provided by Audit Firms}

\begin{tabular}{|l|c|}
\hline Services & \# of Audit Firms \\
\hline Independent Audit & 227 \\
\hline Tax Audit & 202 \\
\hline Corporate Finance/Financial Services & 145 \\
\hline Internal Audit/Internal Control & 106 \\
\hline Risk Management & 42 \\
\hline Digitalization/Information Technologies & 24 \\
\hline Other & 67 \\
\hline
\end{tabular}

As shown in the table above, unsurprisingly almost all of the firms provide independent audit and tax audit. At the same time, more than half of the companies perform advisory services in corporate finance and internal audit issues. Only 24 firms have services about Digitalization/Information Technologies. Approximately 90 percent of the sample have no disclosure about Digitalization/Information Technologies services.

Table 4: Digitalization/ Information Technology Services Provided by Firms

\begin{tabular}{|l|c|}
\hline Services & \# of Audit Firms \\
\hline IT Audit & 20 \\
\hline Cyber Security & 13 \\
\hline
\end{tabular}




\begin{tabular}{|l|l|}
\hline Big data/Data Analytics & 8 \\
\hline Digitalization & 7 \\
\hline Artificial Intelligence & 5 \\
\hline Blockhain & 5 \\
\hline Cloud Computing & 5 \\
\hline ERP & 5 \\
\hline IoT & 1 \\
\hline Robotic Process Automation & 1 \\
\hline Social Media Audit & 1 \\
\hline
\end{tabular}

When the disclosures of the companies providing services on digitalization issues are examined, it is seen that IT audit and cyber security are the leading services. Big four provide services about promising and developing digitalization issues which are big data, Al, Blockchain, Cloud Computing and ERP. And also they disclose infrastructure investments about these topics.

In order to find out the effect of digitalization on the continuing education of audit professionals, the disclosures and transparency reports of firms were examined. The results of the examination of the transparency reports of 64 companies authorized for Public Administration (PIE) Audit are presented in table 5.

Table 5: Continuing Education Topics

\begin{tabular}{|l|c|}
\hline Continuing Education & \# of Audit Firms \\
\hline Accounting/Financial Statements & 58 \\
\hline IFRS & 42 \\
\hline Tax & 42 \\
\hline Auditing Standards & 35 \\
\hline IT/IT Audit & 24 \\
\hline Communication & 21 \\
\hline Ethics & 19 \\
\hline Money \& Banking & 19 \\
\hline Corporate Governance & 18 \\
\hline Risk Management & 17 \\
\hline Financial Law & 11 \\
\hline Digitalization & 4 \\
\hline Team Work & 2 \\
\hline Other & 21 \\
\hline
\end{tabular}

Most audit firms preferred to provide education to their employees on accounting/financial statements, IFRS and tax issues. 24 firms provide education about IT/IT audit topics. Only big four provides education about digitalization topics which are big data/data analytics, artificial intelligence, blockhain, cloud computing, cyber security.

\section{CONCLUSION}

In this study websites of 235 audit firms authorized by POA and transparency reports of 64 companies authorized for PIE audit were investigated to determine current situation of effects digitalization has on the tools and working methods of the audit profession.

It has been concluded that almost all audit companies provide services for independent audit and tax audit. (Respectively $95 \%$ and $85 \%$ ). These are followed by financial services and internal audit issues. (Respectively $61 \%$ and $45 \%$ ).

Only Big Four invest the necessary infrastructure and human resources in addition to providing services in these matters. In spite of all these technological developments, only 24 companies provide education to their employees for IT / IT audits. Only Big Four provide education for digital technologies to their employees.

As a result, with the effect of digitalization, Information technologies have gained importance. But the audit firms have not yet made the necessary investment in these areas. $90 \%$ of audit firms do not provide services in these areas and do not make infrastructure and human resources investments. These audit firms are mainly focused on tax audit. The majority of customers are SMEs. It is quite natural that Big Four, which audit larger companies, make investments and services in these areas. 
For further part of the study, the survey will be conducted to auditors to determine the effect of Digitalization on the audit profession.

\section{REFERENCES}

Alles, M., \& Gray, G. L. (2015). The Pros and Cons of Using Big Data in Auditing: a Synthesis of the Literature and a Research Agenda. Awaiting Approval, 1-37.

Aslan, Ü., \& Özerhan, Y. (2017). Big Data, Muhasebe Ve Muhasebe Mesleği, Muhasebe Bilim Dünyası Dergisi, 19(4); 862-883

Connolly, S. (2012). 7 Key Drivers for the Big Data Market. Blog posting, http://hortonworks.com/blog/7-key-drivers-for-the-big-data-market

Deloitte (2017). Blockchain Technology and Its Potential Impact on the Audit and Assurance Profession, https://www. aicpa.org

E\&Y. 2018 https://www.ey.com/en_us/assurance/why-ai-is-both-a-risk-and-a-way-to-manage-risk

Fanning, K., \& Centers, D. P. (2016). Blockchain and Its Coming Impact on Financial Services. Journal of Corporate Accounting \& Finance, 27(5), 53-57.doi:10.1002/jcaf.22179

FAR. (2016). Nyckeln till framtiden. FAR. Retrieved from https://www.far.se/globalassets/trycksaker-pdf/nyckeln-till-framtiden_uppslag.pdf

Flint, D. (1988). Philosophy and principles of auditing: An introduction. Macmillan Education LTD.

IIA. (2016). Global Perspectives and Insights: Emerging Trends, Issue 5.

Issa, H., Sun, T., \& Vasarhelyi, M. A. (2016). Research Ideas for Artificial Intelligence in Auditing: The Formalization of Audit and Workforce Supplementation. Journal of Emerging Technologies in Accounting, 13(2), 1-20.doi:10.2308/jeta-10511

Karlsen A. \& Wallberg M. The effects of digitalization on auditors' tools and working methods: A study of the audit profession. http://www.divaportal.org/smash/get/diva2:1115922/FULLTEXT01.pdf.

Kiesow, A., Zarvic, N., \& Thomas, O. (2014). Continuous Auditing in Big Data Computing Environments: Towards an Integrated Audit Approach by Using CAATTs. In GI-Jahrestagung pp. 901-912.

McKinsey, (2011). Big data: The next frontier for innovation, competition, and productivity. McKinsey Global Institute, June. http://www.mckinsey.com/insights/business_technology/big_data_the_next_frontier_for_innovation

Ovenden, J. (2017). Will Render Accountants Irrelevant?, https://channels.theinnovationenterprise.com/articles/will-blockchainrenderaccountants-irrelevant

Öz, Y. (2016) Bulut Bilişim (Cloud Computing) ve Muhasebe Bartın Üniversitesi İktisadi ve İdari Bilimler Fakültesi Dergisi 7 (13), 63-79.

Qian, L., Luo, Z., Du, Y., and Guo, L. (2009). Cloud computing: An overview. Berlin, Germany: Springer, pp. 626-631.

Sabillon, R., Serra-Ruiz, J., Cavaller, V., \& Cano, J. (2017). A Comprehensive Cybersecurity Audit Model to Improve Cybersecurity Assurance: The CyberSecurity Audit Model (CSAM). In 2017 International Conference on Information Systems and Computer Science (INCISCOS) (pp. 253-259). IEEE.

Türker, M. (2018). Dijitalleşme Sürecinde Küresel Muhasebe Mesleğinin Yeniden Şekillenmesine Bakış. World of Accounting Science, 20(1).

Uçma T., \& Kurt G., (2018). Blockchain Technology in Accounting and Auditing, Suleyman Demirel University The Journal of Faculty of Economics and Administrative Sciences, Vol.23, No.2, pp.467-481. 